\title{
Aquaporin-4 Gene Polymorphisms in Neuromyelitis Optica and Recurrent Optic Neuritis
}

\author{
Nöromiyelitis Optika ve Relapslı Enflamatuvar Optik Nöropati Hastalı̆̆1 ve Aquaporin-4
} Gen Polimorfizmi

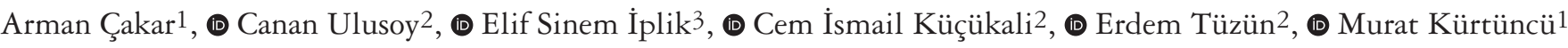

${ }^{1}$ Istanbul University, Istanbul Faculty of Medicine, Department of Neurology, Istanbul, Turkey

2Istanbul University, Aziz Sancar Institute for Experimental Medical Research, Department of Neuroscience, Istanbul, Turkey

3Istanbul Yeni Yuzyil University Faculty of Pharmacy, Department of Biochemistry, Istanbul, Turkey

\begin{abstract}
Objective: Although Aquaporin-4 (Aqp-4) gene polymorphisms have been extensively studied in neuromyelitis optica spectrum disorder (NMOSD), there is little evidence on the involvement of $A q p-4$ in the pathogenesis of relapsing optic neuritis (RON).

Materials and Methods: In our study, we recruited patients who were followed by Istanbul University, Istanbul Faculty of Medicine, Department of Neurology, Multiple Sclerosis and Myelin Disorders Unit between 1979 and 2015. Blood samples of the patients were genotyped for potential variants in the exons and the nearby regions of $A q p-4$ gene.

Results: The $A q p-4$ gene was sequenced in 15 patients with RON who were seronegative, 33 patients with NMOSD, and 30 healthy controls. None of the patients showed previously described single nucleotide polymorphisms (SNPs). Three new SNPs were identified in non-exonic regions of the gene. One intronic SNP located in close proximity to the fifth exon had a higher prevalence in patients with RON than patients with NMOSD and healthy controls.
\end{abstract}

Conclusion: $A q p-4$ SNPs show a considerable heterogeneous geographic distribution and might be involved in RON pathogenesis.

Keywords: Neuromyelitis optica, recurrent optic neuritis, polymorphism aquaporin- 4

$\ddot{O} \mathbf{z}$

Amaç: Aquaporin-4 (Aqp-4) gen polimorfizmi nöromiyelitis optika spektrum bozukluğu (NMOSD) üzerinde oldukça fazla çalışılmış ancak relapslı optik nöropati patogenezi üzerindeki rolü henüz tam olarak bilinmemektedir.

Gereç ve Yöntem: Hastalar, İstanbul Üniversitesi İstanbul Tıp Fakültesi, Nöroloji Anabilim Dalı Multipl Skleroz ve Miyelin Hastalıkları Birimi tarafından 1979 ve 2015 yılları arasında takip edilen hastalar arasından seçilmiştir. Hastalardan alınan kan örnekleri ile Aqp-4 geninin ekzonları ve ekzonlara komşu bölgeleri dizilenmiş ve olası farklılıklar açısından taranmıştır.

Bulgular: Aqp-4 geni 15 relapslı enflamatuvar optik nöropati, 33 NMOSD spektrum bozukluğu ve 30 sağlıklı kontrol üzerinde çalışılmışır. Hastalar üzerinde tanımlanan tek nükleotid polimorfizmleri (SNPs) gözlenmemiştir. Hasta ve sağlıklı kontrollerde üç adet yeni tanımlanan SNP saptanmıştır. Beş intronik bölgede yer alan, bazda meydana gelen transisyonunun tekrarlayan optik nörit (RON) grubunda diğger gruplara kıyasla daha fazla olduğu görülmüştür.

Sonuç: Aqp-4 geni oldukça heterojen bir izlenim vermiş olup RON patogenezinde rolü olduğunu düşünülmektedir.

Anahtar Kelimeler: Nöromiyelitis optika, relapslı enflamatuvar optik nöropati, aquaporin-4 gen polimorfizmi

\section{Introduction}

The significance of genetic polymorphisms in inflammatory demyelinating diseases of the central nervous system (CNS) is increasingly being recognized. Although the genetic features of multiple sclerosis have been meticulously scrutinized in the last few decades, polymorphisms associated with neuromyelitis optica spectrum disorders (NMOSD) have only recently been brought under spotlight. In this context, several recent studies have investigated aquaporin-4 (Aqp-4) gene polymorphisms in $\operatorname{NMOSD}(1,2)$.

\footnotetext{
Address for Correspondence/Yazışma Adresi: Erdem Tüzün MD, Istanbul University, Aziz Sancar Institute for Experimental Medical Research, Department of Neuroscience, Istanbul, Turkey

Phone: +90 2124142000 E-mail: drerdem@yahoo.com ORCID: orcid.org/0000-0002-4483-0394

Received/Geliş Tarihi: 18.02.2019 Accepted/Kabul Tarihi: 27.02.2020

${ }^{\circ}$ Copyright 2020 by Turkish Neurological Society

Turkish Journal of Neurology published by Galenos Publishing House.
} 
Single nucleotide polymorphisms (SNPs) of the $A q p-4$ gene are anticipated to affect the expression level, molecular structure, orthogonal array formation ability, and even the immunogenicity of the $A q p$-4 protein $(3,4)$. However, $A q p$-4 gene analysis has given conflicting results in NMOSD. $A q p-4$ gene variants described in most studies have usually been identified in a small number of patients with NMOSD without having been confirmed by other researchers, indicating the geographic heterogeneity of the gene. Moreover, many researchers have failed to find a robust enough association between $A q p-4$ polymorphisms and NMO, reducing the confidence on the involvement of the $A q p-4$ gene variants in NMO pathogenesis $(2,5,6,7)$.

On the other hand, polymorphisms related with another inflammatory demyelinating disorder, recurrent optic neuritis (RON), have been scarcely investigated. A search of the English literature reveals a couple of studies, which found only a few Aqp-4 polymorphisms, mostly in a small proportion of patients with RON who were $A q p-4$ antibody-positive, who fulfill the NMOSD criteria $(1,3)$. In this study, we aimed to evaluate the contribution of the SNPs in the $A q p-4$ gene to the susceptibility of NMOSD and RON.

\section{Materials and Methods}

$A q p$ - 4 gene polymorphisms were investigated in 15 patients with RON (10 women, 5 men; average age \pm standard deviation, $34.4 \pm 12.8$ years). Thirty-three patients who satisfied the NMOSD criteria (21 Apq-4 antibody positive, 28 women, 5 men; $34.6 \pm 11.3$ years) and 30 age/sex-matched healthy controls (22 women, 8 men; $33.0 \pm 12.5$ years) were also included. The patients with RON had normal cranial and spinal magnetic resonance imaging, chest $\mathrm{X}$-ray, blood biochemistry, total blood count, vitamin B12, folate and angiotensin-converting enzyme levels. They were also negative for $A q p-4$ antibodies, thyroid antibodies, anti-nuclear antibodies, and a broad panel of rheumatologic/vasculitic disorders. Disease duration was 9.6 \pm 7.6 and $6.2 \pm 7.2$ years for the patients with NMOSD and $\mathrm{RON}$, respectively. The average attack number was $3.2 \pm 0.7$ (range $=2-5$ ) for patients with RON. All patients with RON showed unilaterally or bilaterally increased visual evoked potential P100 values. Aqp-4 antibody was detected in the sera of patients using a cell-based assay using a commercial kit (Euroimmun, Luebeck, Germany) and found negative in all patients with RON and healthy controls.

Our study comprised patients who were followed by Istanbul University, Istanbul Faculty of Medicine, Department of Neurology,
Multiple Sclerosis and Myelin Disorders Unit between 1979 and 2015. The study was approved by the Medical Ethics Committee of Istanbul Medical Faculty (2014/395) and all participants (i.e. controls, patients) gave written informed consents. Peripheral blood samples were collected and stored at $-20^{\circ} \mathrm{C}$. Genomic DNA was extracted using the QIAamp DNA Blood Maxi Kit (Qiagen, Hilden, Germany). The target DNA was amplified using polymerase chain reaction (PCR) (Applied Biosystems, USA) with previously published primer pair sequences and PCR conditions (5). Sequencing was performed using an ABI Prism 3100 Genetic Analyser system (Applied Biosystems) and the 3'UTR region was included to sequencing studies due to its estimated significance in $A q p-4$ expression.

\section{Statistical Analysis}

Statistical analyses were performed using the SPSS software (version 17, SPSS Inc., Chicago, IL, U.S.A.). Differences in the distribution between the patient and control groups were tested using the chi-square $\left(\chi^{2}\right)$ test, Student's t-test $(p<0.005)$, and the Mann-Whitney $U$ test to find the mean value of results. Bonferroni correction was used for multiple comparisons.

\section{Results}

The sequencing analysis revealed no exonic or intronic SNPs previously reported in NMOSD or RON. However, two SNPs were identified in intronic regions close to the $5^{\text {th }}$ exon. An additional SNP was found in the 3'UTR region. The intronic rs26856556 SNP had a significantly higher frequency in patients with RON than in patients with NMOSD and healthy controls, and the frequencies of the other two SNPs were comparable among the study groups (Table 1).

\section{Discussion}

According to the literature there are several studies about $A q p-4$ and neuromyelitis optica that resulted similar to us with different outcomes (Table 2) $(8,9,10,11,12,13,14)$. We have thus performed the first $A q p-4$ gene analysis in a Turkish cohort with inflammatory demyelinating CNS disorders. In keeping with previous reports $(2,6,7)$, we failed to identify a consistent and reproducible SNP in the $A q p-4$ gene that could reliably be associated with NMOSD. Instead, we found new SNPs in the intron and 3'UTR regions that were in close proximity to the fifth exon, thus confirming the heterogeneous distribution of $A q p-4$ gene polymorphisms among diverse geographic locations. There

Table 1. Allele frequencies of SNPs of the Aqp-4 gene among NMOSD and RON patients and healthy controls

\begin{tabular}{|c|c|c|c|c|c|c|c|c|}
\hline \multirow{2}{*}{ SNP } & \multirow{2}{*}{$\begin{array}{l}\text { Gene } \\
\text { location }\end{array}$} & \multirow{2}{*}{ Alleles } & \multicolumn{3}{|c|}{$\begin{array}{l}\text { Polymorphism frequencies } \\
\text { Number of cases, }(\%)\end{array}$} & \multicolumn{3}{|l|}{$\mathrm{p}$ values* } \\
\hline & & & NMOSD (33) & RON (15) & $\mathrm{HC}(30)$ & $\begin{array}{l}\text { NMOSD vs } \\
\text { RON }\end{array}$ & $\begin{array}{l}\text { NMOSD vs } \\
\text { HC }\end{array}$ & $\begin{array}{l}\text { RON vs } \\
\text { HC }\end{array}$ \\
\hline rs26856962 & Intron & $\mathrm{T} \rightarrow \mathrm{G}$ & $8(24.2 \%)$ & $3(20.0 \%)$ & $7(23.3 \%)$ & $>0.999$ & $>0.999$ & $>0.999$ \\
\hline rs26856556 & Intron & $\mathrm{T} \rightarrow \mathrm{C}$ & $2(6.1 \%)$ & $6(40.0 \%)$ & $2(6.7 \%)$ & 0.008 & $>0.999$ & 0.011 \\
\hline rs26855249 & 3'UTR & $\mathrm{C} \rightarrow \mathrm{A}$ & $17(51.5 \%)$ & $9(60.0 \%)$ & $13(43.3 \%)$ & 0.756 & 0.616 & 0.353 \\
\hline
\end{tabular}




\begin{tabular}{|c|c|c|c|}
\hline Authors & Title & $\begin{array}{l}\text { Journal information and years } \\
\text { of published }\end{array}$ & $\begin{array}{l}\text { Reference } \\
\text { number }\end{array}$ \\
\hline Wang et al. & $\begin{array}{l}\text { The single nucleotide polymorphism } \\
\text { site of aquaporin- } 4 \text { gene in patients with neuromyelitis optica }\end{array}$ & Exp Ther Med 2017;14:6017-6021 & (9) \\
\hline Chu et al. & $\begin{array}{l}\text { Association between the single nucleotide polymorphism } \\
\text { and the level of aquaporin-4 protein expression in Han and } \\
\text { Minority Chinese with inflammatory demyelinating diseases of } \\
\text { the central nervous system }\end{array}$ & Mol Neurobiol 2016;53:2878-2885 & (10) \\
\hline Wei et al. & $\begin{array}{l}\text { Human aquaporin- } 4 \text { gene polymorphisms in Chinese patients } \\
\text { with neuromyelitis optica }\end{array}$ & J Neuroimmunol 2014;274:192-196 & (11) \\
\hline Matiello et al. & $\begin{array}{l}\text { NMO Genetics Collaborators. Genetic analysis of aquaporin- } 4 \text { in } \\
\text { neuromyelitis optica }\end{array}$ & Neurology 2011;77:1149-1155 & (13) \\
\hline Ban et al. & $\begin{array}{l}\text { Polymorphisms in the neuromyelitis optica auto-antigen AQP- } 4 \\
\text { and susceptibility to multiple sclerosis }\end{array}$ & J Neurol 2007;254:398-399 & (14) \\
\hline \multicolumn{4}{|c|}{ Aqp-4: Aquaporin- 4 , NMO: Neuromyelitis optica } \\
\hline
\end{tabular}

are several reports in the literature focusing on the genetic risk factors of NMOSD. In a recent report, a variation in the major histocompatibility gene was associated with an increased risk of Aqp-4 antibody seropositivity (15). Other studies suggested that SNPs and copy number variations in CD58, PDZD2, MIF, $\mathrm{CH} 25 \mathrm{H}$ might influence the disease characteristics in different ways $(16,17,18,19)$.

Intronic SNPs often alter the expression levels of genes and thus the intronic $A q p-4 \mathrm{SNP}$ with high prevalence in RON might potentially influence the clinical course of the disease. There is some evidence suggesting that $A q p-4$ is involved in brain edema and inflammation. $A q p-4$ deficient mice have been reported to give altered brain edema and inflammation responses to hypoxiaischemia (20). Moreover, some patients with NMOSD with certain $A q p$-4SNPs were reported to display other autoimmune disorders such as systemic lupus erythematosus further emphasizing the association between $A q p$ - 4 , autoimmunity and inflammation (4).

A major drawback of our study is the low case number and thus low statistical power. Secondly, myelin oligodendrocyte glycoprotein (MOG) antibodies were not investigated in our patients. Distinct immunopathogenic features appear to be involved in the MOG-antibody associated NMO and RON. Therefore, we would recommend investigating common genetic variants in different antibody subgroups of NMO and RON in larger cohorts in the future.

\section{Conclusion}

Notably, we found an intronic SNP in a sizeable portion of patients with $\mathrm{RON}$, implying a role for the $A q p-4$ protein in the pathogenesis of RON. Further studies are warranted for the delineation of the role of aquaporin molecules in the pathogenesis of demyelinating disorders.

\section{Ethics}

Ethics Committee Approval: The study was approved by the Medical Ethics Committee of Istanbul Medical Faculty (2014/395).

Informed Consent: Consent form was filled out by all participants.

Peer-review: Externally peer-reviewed.

\section{Authorship Contributions}

Surgical and Medical Practices: A.Ç., M.K., Concept: E.T., M.K., C.İK., Design: E.T., C.İ.K., E.S.İ., Data Collection or Processing: C.U., A.Ç., E.S.İ., Analysis or Interpretation: E.T., C.İ.K., E.S.İ., C.U., A.Ç., M.K., Literature Search: E.S.İ., C.U., A.Ç., Writing: E.S.İ., C.U., A.Ç., E.T.

Conflict of Interest: No conflict of interest was declared by the authors.

Financial Disclosure: Research Fund of the University of Istanbul. Project number: 44692.

\section{References}

1. Mai W, Hu X, Lu Z, Qiu W, Peng F, Wang Y. Preliminary study on the association of AQP4 promoter polymorphism with anti-aquaporin- 4 antibody positivity in southern Han Chinese patients with idiopathic demyelinating disorders of central nervous system. J Neuroimmunol 2013;255:75-80.

2. Wei Q, Yanyu C, Rui L, et al. Human aquaporin 4 gene polymorphisms in Chinese patients with neuromyelitis optica. J Neuroimmunol 2014;274:192196.

3. Chu L, Dai Q, Xu Z, et al. Association between the single nucleotide polymorphism and the level of aquaporin- 4 protein expression in Han and 
minority Chinese with inflammatory demyelinating diseases of the central nervous system. Mol Neurobiol 2016;53:2878-2885.

4. Matiello M, Schaefer-Klein JL, Hebrink DD, et al. Genetic analysis of aquaporin-4 in neuromyelitis optica. Neurology 2011;77:1149-1155.

5. Ogasawara M, Meguro A, Sakai T, et al. Genetic analysis of the aquaporin-4 gene for anti-AQP4 antibody-positive neuromyelitis optica in a Japanese population. Jpn J Ophthalmol 2016;60:198-205.

6. Park TJ, Kim JH, Kim HJ, et al. Lack of association between AQP4 polymorphisms and risk of inflammatory demyelinating disease in a Korean population. Gene 2014;536:302-307.

7. Yang TT, He Y, Xiang YJ, et al. No association of AQP4 polymorphisms with neuromyelitis optica and multiple sclerosis. Transl Neurosci 2016;7:7683.

8. Xie JL, Liu J, Lian ZY, et al. Association of GTF2IRD1-GTF2I polymorphisms with neuromyelitis optica spectrum disorders in Han Chinese patients. Neural Regen Res 2019;14:346-353.

9. Wang QS, Xiao HQ, Chen HX, Liu YP, Ding XD. The single nucleotide polymorphism site of aquaporin-4 gene in patients with neuromyelitis optica. Exp Ther Med 2017;14:6017-6021.

10. Chu L, Dai Q, Xu Z, et al. Association Between the Single Nucleotide Polymorphism and the Level of Aquaporin-4 Protein Expression in Han and Minority Chinese with Inflammatory Demyelinating Diseases of the Central Nervous System. Mol Neurobiol 2016;53:2878-2885.

11. Wei Q, Yanyu C, Rui L, et al. Human aquaporin 4 gene polymorphisms in Chinese patients with neuromyelitis optica. J Neuroimmunol 2014;274:192196.
12. Mai W, Hu X, Lu Z, Qiu W, Peng F, Wang Y. Preliminary study on the association of AQP4 promoter polymorphism with anti-aquaporin-4 antibody positivity in southern Han Chinese patients with idiopathic demyelinating disorders of central nervous system. J Neuroimmunol 2013;255:75-80.

13. Matiello M, Schaefer-Klein JL, Hebrink DD, Kingsbury DJ, Atkinson EJ, Weinshenker BG. NMO Genetics Collaborators. Genetic analysis of aquaporin-4 in neuromyelitis optica. Neurology 2011;77:1149-1155.

14. Ban M, Walton A, Goris A, Gray J, Compston A, Sawcer S. Polymorphisms in the neuromyelitis optica auto-antigen AQP4 and susceptibility to multiple sclerosis. J Neurol 2007;254:398-399.

15. Estrada K, Whelan CW, Zhao F, et al. A whole-genome sequence study identifies genetic risk factors for neuromyelitis optica. Nat Commun 2018;9:1929.

16. Siuko M, Valori M, Kivelä T, et al. Exome and regulatory element sequencing of neuromyelitis optica patients. J Neuroimmunol 2015;289:139-142.

17. Liu J, Shi Z, Lian Z, et al. Association of CD58 gene polymorphisms with NMO spectrum disorders in a Han Chinese population. J Neuroimmunol 2017;309:23-30.

18. Forwell AL, Bernales CQ, Ross JP, et al. Analysis of $\mathrm{CH} 25 \mathrm{H}$ in multiple sclerosis and neuromyelitis optica. J Neuroimmunol 2016;291:70-72.

19. Brill L, Vaknin-Dembinsky A, Zveik O, Haham N, Miller K, Benedek G. MIF $-173 \mathrm{G} / \mathrm{C}$ polymorphism is associated with NMO disease severity. J Neuroimmunol. 2020;339:577120.

20. Liu S, Mao J, Wang T, Fu X. Downregulation of aquaporin-4 protects brain against hypoxia ischemia via anti-inflammatory mechanism. Mol Neurobiol 2017;54:6426-6435. 